\title{
Editorial
}

\section{'Gas' a Popular Term but it may not be Gastric Ulcer}

\author{
MMSU Islam
}

"I am suffering from gas" "I am taking antacids for 20 years" is a very common complaint encountered by almost all doctors especially by gastroenterology. If asked what actually they mean by gas, there are diverse response to cite some examples, "gas means gas" "may gas in not in the abdomen but in my head", "my gas comes out through gas ear, nose, or even scalp". There will be a lot of story if all doctors share their experience about gas, a few days earlier a patient came with opisthotonus and complaining that there is entrapment of gas within abdomen and chest but not responding to even injectable ...prazols. unfortunately he was suffering from tetanus. Abdominal problem for which patients commonly complains gas are belching, abdominal pain, anorexia, nausea, vomiting, abdominal fullness, audible bowel sounds, incomplete evacuation of bowel, passing excessive flatus etc. Besides gastrointestinal disorders, patient with ischemic heart disease, uncontrolled hypertension, vestibular disorders, migraine and different somatoform disorders commonly presents to us with the complains of 'Gas'.

What is intestinal gas? Five gases namely $\mathrm{N}_{2}, \mathrm{O}_{2}, \mathrm{CO}_{2}$, $\mathrm{H}_{2}$ and $\mathrm{CH}_{4}$ account for more than $99 \%$ of intestinal gas of which $\mathrm{N}_{2}$ is predominant. In the fasting state, healthy gastrointestinal tract contains only about $100 \mathrm{ml}$ of gas distributed almost equally among six compartmentsstomach, small intestine, ascending colon, transverse colon, descending colon and pelvic colon. Postprandially, the volume of gas increases by $65 \%$, primarily in the pelvic colon. Gas enters the stomach primarily via air swallowing and leaves the stomach via belching, absorption or enters into the duodenum. In the proximal small intestine, interaction of bicarbonate and acid produces large quantities $\mathrm{CO}_{2}$. Gas producing bacteria in the colon ferment unabsorbed substrates and release $\mathrm{H}_{2}, \mathrm{CO}_{2}$ and Sulfur containing gas. Other bacteria uses this gases, some diffuses into blood and eliminated via breath and remainder eliminated via anus ${ }^{1}$.

The rate and volume of gas excretion per rectum is highly variable. Normal volume ranges from 500 to $1500 \mathrm{ml}$ per day and normal number of passage of gas per rectum ranges from 6-20 (mean 13.6) times/day ${ }^{2}$.

Address of correspondence :

Dr. M.M.Shahin-U1-Islam, MBBS, FCPS (Medicine), MD

(Gastroenterology), Assistant Professor, Department of Gastroenterology, FMC, Faridpur. Mobile No: +88-01711986290

Email: shahin52dmc@gmail.com
Excessive gas belching or eructation is almost always a psychological disorder and is aggravated by rapid eating, smoking, drinking carbonated beverage, gum chewing etc. Voluminous but odorless flatus is usually results from bacterial fermentation of undigested carbohydrates. Excessive odoriferous flatus usually produced by sulfate containing substrate like cruiciferous vegetables, meats and eggs ${ }^{1}$.

So, what should we do? It is the history which will give the answer. First thing is clarification. It should be cleared from patient that 'what they actually mean by gas?' Gas and Gastric ulcer are not the same thing so obviously $\mathrm{H}_{2}$ receptor blockers or proton pump inhibitors (PPIs) are not the answer for all gases. Prompt diagnosis of life threatening illness with immediate treatment can save life of patient with so called 'Gas'; while assurance and life style modification may be sufficient for majority. If we proceed is such a way, we can reduce injudicious use of PPIs (Probably the most commonly sold drug of our country) and can save a lot of money.

\section{References :}

1. Fernando A, Michael DL. Intestinal Gas. In: Mark F, Lawrence SF, Lawrence JB, Editors. Sleisenger and Fordtrean's Gastrointestinal and Liver Disease: Pathophysiology/Diagnosis/Management. 9th edition 2010. Philadelphia: Elsevier; 2010. p. 233-40.

2. David JK. Approach to the Patient with Gastrointestinal Disorders. In: Scot LF, Kenneth RM, James HG, editors. Current Diagnosis \& Treatment of Gastroenterology. United States: McGraw-Hill; 2003. p. 9. 